\title{
Permainan Pangkak Igik Karet Sebagai Media Berhitung
}

\author{
Yopa $^{1}$, Devi Narasiska ${ }^{2}$, Nadia $^{3}$, Yudi Yunika Putra ${ }^{4}$ \\ 1,2,3,4 Universitas Muhammadiyah Bangka Belitung, \\ Jl. KH A Dahlan, Mangkol, Kabupaten Bangka Tengah, Kepulauan Bangka Belitung \\ yudi.yunikaputra@unmuhbabel.ac.id
}

\begin{abstract}
The problem that occurs today is the lack of student interest in mathematics so that students' numeracy skills tend to be weak. Therefore, this writing needs to be used as material in improving students' numeracy skills through arithmetic media in which there are games. The purpose of this study was to describe the role of the game of rubber skippers as a media for counting. However, in this literature review, no data was obtained about the game of rubber stigmas, so it used research data about the game as a media for counting. Literature review was chosen as a method in this study with a systematic review procedure. Collecting data in the form of secondary data in the form of research results that have been published in the Online Journal System (OJS) and books relevant to the study with a total of 37 references. The results showed that: (1) the pangkik rubber game can be assumed as a learning medium to develop students 'numeracy concepts, (2) for students who are familiar with the concept of arithmetic, the game of lap rubber rigik can improve students' numeracy skills, (3) the game of lap igik Rubber provides a fun learning environment that can motivate students, and (4) the game of rubber feet as a learning medium can improve students' cognitive abilities so that it is effectively applied to mathematics subjects.
\end{abstract}

Keywords: Counting, Media, Pangkak Igik Karet

\begin{abstract}
Abstrak
Permasalahan yang terjadi saat ini adalah kurangnya minat belajar siswa pada mata pelajaran matematika sehingga kemampuan berhitung siswa cenderung lemah. Oleh karena itu, penulisan ini perlu dilakukan untuk dijadikan bahan dalam meningkatkan kemampuan berhitung siswa melalui media berhitung yang di dalamnya terdapat permainan. Tujuan dari penelitian ini adalah menggambarkan peran permainan pangkak igik karet sebagai media berhitung. Tetapi dalam kajian literatur ini tidak didapatkan data tentang permainan pangkak igik karet sehingga menggunakan data penelitian tentang permainan sebagai media berhitung. Tinjauan literatur (literature review) dipilih sebagai metode dalam penelitian ini dengan prosedur systematic review. Pengumpulan data berupa data sekunder berupa hasil penelitian yang telah diterbitkan dalam Online Journal System (OJS) dan buku yang relevan dengan kajian dengan jumlah 37 referensi. Hasil penelitian menunjukkan bahwa: (1) permainan pangkak igik karet dapat diasumsikan sebagai media belajar untuk membangun konsep berhitung siswa, (2) bagi siswa yang sudah mengenal konsep berhitung, permainan pangkak igik karet dapat meningkatkan kemampuan berhitung siswa, (3) permainan pangkak igik karet menyediakan lingkungan belajar yang menyenangkan yang dapat memotivasi siswa, dan (4) permainan pangkak igik karet sebagai media pembelajaran dapat meningkatkan kemampuan kognitif siswa sehingga efektif diterapkan pada mata pelajaran matematika.
\end{abstract}

Kata kunci: Berhitung, Media, Pangkak Igik Karet

Copyright (c) 2021 Yopa, Devi Narasiska, Nadia, Yudi Yunika Putra

$\triangle$ Corresponding author: Yudi Yunika Putra

Email Address: yudi.yunikaputra@ unmuhbabel.ac.id (Jl. KH A Dahlan, Mangkol, Kepulauan Bangka Belitung)

Received 28 November 2020, Accepted 15 Februari 2021, Published 17 Februari 2021

\section{PENDAHULUAN}

Faktor-faktor yang mempengaruhi proses pembelajaran di sekolah di antaranya: peserta didik, guru, kurikulum pendidikan, media pembelajaran, metode pembelajaran, dan sebagainya. Media 
pembelajaran menurut Heinich dikutip oleh (Arsyad, 2011) adalah suatu penghubung antara sumber dan penerima yang di dalamnya terdapat pengajaran instruksional. Faktor-faktor tersebut menjadi pendukung dalam sebuah proses pembelajaran (Pane \& Muhammad, 2017). Sampai saat ini, pembelajaran matematika masih dianggap sebagai pembelajaran yang sulit dan sangat dihindari oleh banyak siswa karena konsep-konsep matematika yang abstrak sehingga siswa kesulitan untuk memahami (Laurens, Batlolona, Batlolona, \& Leasa 2018). Kehilangan minat belajar akan pembelajaran matematika merupakan salah satu faktor yang mempengaruhi hal tersebut. Maka perlu ditanamkan prinsip pada siswa sejak dini agar pandangan mereka akan matematika menjadi terarah (Agustin, 2019). Menurut (Nataliya, 2015) kemampuan berhitung dikatakan baik jika siswa sanggup untuk menyelesaikan persoalan bilangan seperti menambahkan bilangan, mengurangi bilangan, mengalikan bilangan, dan membagikan bilangan dimana dalam proses mengoperasikan bilangan tersebut siswa perlu menalar dan mampu berpikir aljabar. Kemampuan berhitung pada dasarnya dimiliki oleh setiap siswa yang karakteristik perkembangannya dimulai dari lingkungan sekitar, sejalan dengan perkembangan yang dapat meningkatkan ketahap penambahan dan pengurangan (Susanto, 2011). Salah satu penyebab lemahnya kemampuan siswa akan operasi hitung adalah kurang menariknya proses pembelajaran dan variasi penerapan metode pembelajaran cenderung sedikit (Rukiah, 2018). Sehingga siswa menganggap bahwa matematika itu suatu hal yang sulit, dimana konsep hitungan adalah hal yang dasar dalam matematika (Sakarti, 2018).

Pada penelitian (Fahmi, 2016) menyatakan bahwa siswa bukannya tidak memiliki kemampuan untuk menyerap materi, hanya saja metode guru kurang tepat dalam memberikan metode pembelajaran. Untuk mengubah pandangan siswa akan pembelajaran yang dianggapnya kurang menyenangkan, maka diperlukan suatu kegiatan yang menyenangkan pula (Rahmatin, 2016). Dijelaskan pada penelitian (Hariastuti, 2017) bahwa permainan merupakan salah satu cara khusus agar siswa dapat dengan mudah memahami konsep dari penjumlahan dan perkalian. Media pembelajaran yang berbasis permainan dapat menumbuhkan ketertarikan siswa dan dapat memotivasi siswa dalam belajar (Falahudin, 2014). Pada hakikatnya, bermain memiliki fungsi dalam beberapa aspek seperti aspek kognitif, aspek perkembangan motorik, aspek perkembangan sosial, penajaman penginderaan, keterampilan, emosi dan kepribadian (Iswinarti, 2010). Melalui permainan siswa akan menemukan hal-hal baru dan dapat berlatih memproses informasi, siswa juga dapat belajar mengendalikan diri serta memahami kehidupan sekitar (Handayani, Dantes, \& Lasmawan, 2013). Menurut (Agusti, Zafirah, Anwar, \& Syafril, 2018) salah satu penentu suksesnya proses pembelajaran adalah media pembelajaran. Salah satu penyebab siswa kurang bersemangat dan merasa bosan pada saat pembelajaran adalah media pembelajaran yang cenderung kurang menarik bagi siswa, sehingga dapat mempengaruhi kemampuan berhitung siswa (Sari, Muslihatun, Cahyaningtyas, Khaimmudin, Fijatullah, \& Nisa', 2019). Media permainan pembelajaran yang menarik bagi siswa akan memperkuat penguasaan matematika siswa (Indrawati \& Suardiman, 2013). Hasil penelitian (Rizal \& 
Hernawati, 2017) menyatakan bahwa media pembelajaran yang di dalamnya terdapat permainan bisa membangkitkan minat belajar siswa.

Permainan pangkak igik karet merupakan permainan tradisional Bangka Belitung yang saat ini sudah jarang dimainkan oleh warga Bangka Belitung. Oleh karena itu penelitian ini perlu dilakukan agar dapat menjawab pemasalahan siswa dalam pembelajaran matematika. Permainan pangkak igik karet tidak hanya dapat meningkatkan kemampuan berhitung siswa, tetapi juga dapat melatih siswa dalam menyusun strategi, serta dapat melatih siswa untuk bertindak teliti dan hati-hati, sehingga pola pikir siswa akan terasah dan terarah, dan berpengaruh terhadap perkembangan siswa. Permainan pangkak igik karet merupakan permainan yang dahulu dimainkan dengan tujuan untuk menghilangkan lelah usai bekerja. Oleh karena itu, Permainan pangkak igik karet akan menumbuhkan semangat dan meningkatkan minat siswa dalam pembelajaran, khususnya pada mata pelajaran matematika.

Permainan tradisional merupakan salah satu dari sekian banyak media pembelajaran yang efektif diterapkan agar kemampuan kognitif siswa dapat meningkat dalam proses pembelajaran khususnya pada mata pelajaran matematika (Siregar \& Lestari, 2018). Permainan tradisional adalah permainan yang diteruskan dan diwariskan kepada tiap generasi yang di dalamnya mengandung nilainilai kebaikan dan dapat bermanfaat bagi perkembangan pada aspek kognitif, perkembangan fisik, pengontrolan emosi siswa (Hasanah \& Pratiwi, 2017). Masing-masing permainan tradisional terdapat aturan sendiri dan dimainkan oleh lebih dari satu orang (Iswinarti, 2010). Siswa secara langsung dapat memperoleh pengalaman dalam mempelajari konsep-konsep yang ada dalam matematika melalui permainan tradisional (Ulya, 2017). Permainan tradisional bekel dan kelereng dapat menjadikan pembelajaran matematika sebagai pembelajaran yang inovatif dan menyenangkan (Mulyatna, Arfatin, \& Seruni, 2020) (Arista, Handayanto, \& Damayani, 2019) pada penelitiannya menyatakan bahwa menggunakan permainan tradisional engklek sebagai media dalam proses pembelajaran matematika dapat memberikan peningkatan pada hasil belajar siswa. Selain itu, permainan tradisional dapat meningkatkan kemampuan interpersonal siswa sekolah dasar (Susanti, Siswati, \& Prasetyo, 2010). Permainan tradisional meong-meongan pada penelitian (Handayani, Dantes, \& Lasmawan, 2013) dapat berpengaruh terhadap kedisiplinan, rasa percaya diri, dan sikap kooperatif siswa. Pada penelitian (Nataliya, 2015) Permainan tradisional congklak sebagai media dalam pembelajaran matematika dapat memberikan peningkatan pada kemampuan berhitung siswa. Begitu juga pada penelitian (Sholihah \& Nur, 2019) yang memodifikasikan permainan ular naga sebagai media dalam pembelajaran dapat meningkatkan kemampuan berhitung anak. Pada penelitian (Mulyani, 2016) permainan dakon yang merupakan permainan tradisional masyarakat Jawa dan dikenal juga di daerah lain bisa melatih siswa agar pandai berhitung sekaligus dapat mengenalkan nilai-nilai budaya kepada siswa dan juga berpengaruh terhadap perkembangan siswa pada aspek kognitif, motorik halus, dan sosial emosional. Berdasarkan penelitian sebelumnya, beberapa penelitian berkaitan dengan media permainan dalam belajar matematika telah banyak dilakukan 
seperti (Novianti, 2015;Muzdalipah \& Yulianto, 2015;Prasetya \& Siti, 2016; Widiyahti, Suprapto \& Adamura, 2015; Fadlillah, 2016) Peneliti menemukan bahwa masih kurang media pembelajaran matematika berbasis permainan tradisional yang sudah jarang dimainkan khususnya permainan pangkak igik karet. sehingga penelitian ini ingin menggambarkan peran permainan pangkak igik karet sebagai media berhitung.

\section{METODE}

Penulisan ini menggunakan metode studi pustaka (literature review) dengan prosedur systematic review dimana peneliti mencari hasil penelitian dan artikel secara sistematis dimulai dari hasil yang berkaitan dengan permainan sebagai media pembelajaran sampai dengan hasil yang berkaitan dengan permainan tradisional sebagai media pembelajaran matematika. Hasil penelitian yang dianalisis adalah penelitian permainan tradisional sebagai media pembelajaran matematika. Tujuan penelitian ini untuk menggambarkan peran permainan pangkak igik karet sebagai media berhitung. Tetapi dalam kajian literatur ini tidak didapatkan data tentang permainan pangkak igik karet sehingga menggunakan data penelitian tentang permainan sebagai media berhitung. Penulisan ini mengkaji temuan dalam literatur yang di dalamnya terdapat pengetahuan dan gagasan sehingga dapat memberikan dan menyampaikan informasi secara teori dan ilmiah terkait peran permainan terhadap kemampuan berhitung. Pengumpulan data dan analisis data berupa data hasil penelitian yang sudah ada (sekunder) seperti data dari jurnal ilmiah, buku, website, dan sumber lain yang terkait dengan jumlah 37 referensi. Referensi yang diambil adalah data-data yang berkaitan dengan permainan sebagai media pembelajaran, permainan tradisional sebagai media pembelajaran, dan permainan tradisional sebagai media pembelajaran matematika. Lima tahapan teknik analisis data yang digunakan dalam penelitian ini berdasarkan model penelitian (Masyhur, 2017) meliputi: pertama, penetapan kata kunci data penelitian. Setelah menetapkan kata kunci, tahap kedua yaitu melakukan pencarian data yang dibutuhkan dalam penelitian. Ketiga, data dikelompokkan berdasarkan kategori tertentu. Keempat, menganalisis yakni mencari keterkaitan antara hasil penelitian yang satu dengan hasil penelitian lainnya dimana data yang dikaji adalah data hasil belajar sebelum dan setelah menggunakan permainan sebagai media pembelajaran, kemudian menyatukan hasil organisasi pada tahap pertama agar menjadi satu kesatuan yang ringkas dan padu. Kelima, menetapkan kesimpulan dari hasil penelitian yang telah dianalisis. Model penelitian kajian literatur seperti yang terlihat pada gambar 1 di bawah.

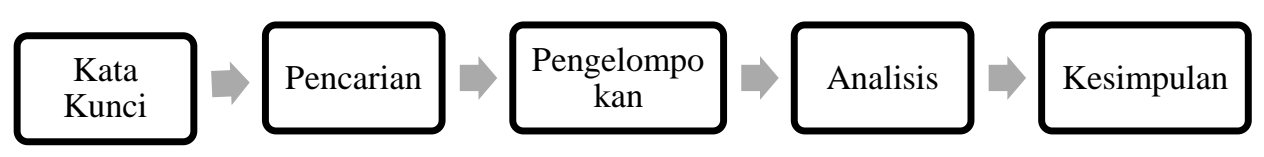

Gambar 1. Model penelitian (Masyhur, 2017) 


\section{Pentapan Analisis Data \\ Pengumpulan \\ Data}

Gambar 2. Road Map Penelitian

\section{HASIL}

Ada banyak jenis permainan salah satunya permainan tradisional yang diteruskan atau diwariskan secara turun-temurun kepada setiap generasi bangsa dan dapat dijadikan media yang efekif dalam proses pembelajaran agar kemampuan kognitif siswa dalam proses pembelajaran khususnya pada mata pelajaran matematika danat meningkat (Siregar \&Lestari.2018)

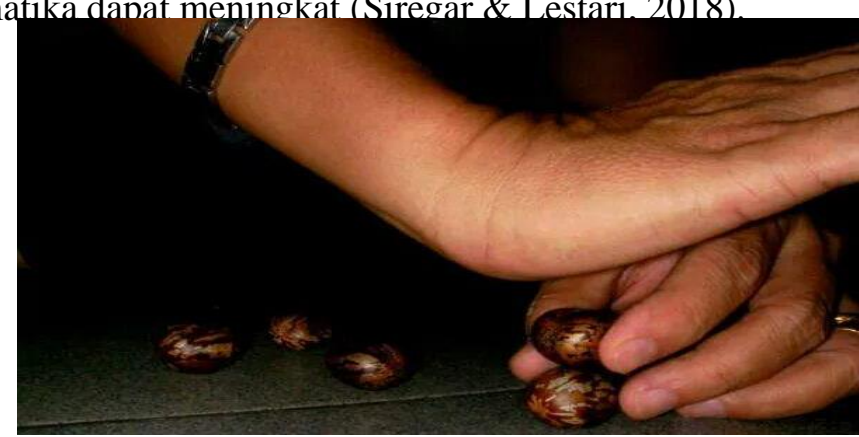

Gambar 3. Permainan Pangkak Igik Karet

Pangkak igik karet dimainkan dengan cara menindih dua biji karet dan ditahan dengan salah satu tangan lalu tangan yang satunya bertugas untuk memecahkan. Lalu biji yang pecah, biji yang tidak pecah, dan jumlah biji yang telah digunakan dapat dihitung.

Data nilai rata-rata berhitung siswa dari beberapa penelitian yang menggunakan permainan sebagai media berhitung dengan hasil penelitian berupa hasil belajjar siswa berdasarkan siklus penelitian seperti pada tabel 1 di bawah.

Tabel 1. Data Nilai Rata-rata Berhitung Siswa

\begin{tabular}{|c|l|c|c|}
\hline No & \multicolumn{1}{|c|}{ Data } & Siklus I (sebelum) & Siklus II (sesudah) \\
\hline 1. & (Nataliya, 2015) & 58,46 & 68,46 \\
\hline 2. & (Rukiah, 2018) & 63 & 75 \\
\hline 3. & (Novianti, 2015) & 36,11 & 66,67 \\
\hline 4. & (Arista, Handayanto, \& & 58,4 & 80,7 \\
& Damayani, 2019) & & \\
\hline
\end{tabular}

Pada masing-masing hasil penelitian, terdapat perbedaan antara nilai rata-rata siklus I dengan nilai rata-rata siklus II kemampuan berhitung siswa yaitu rata-rata nilai siklus II lebih tinggi dibandingkan rata-rata nilai siklus I dimana pada siklus I peneliti belum memberikan permainan sebagai media dalam pembelajaran dan pada siklus II peneliti telah memberikan permainan tradisional congklak sebagai media dalam pembelajaran. Rata-rata nilai dari kemampuan berhitung siswa setelah diberikan 
permainan sebagai media dalam pembelajaran lebih tinggi dibandingkan sebelum diberikan permainan sebagai media berhitung. siswa yang kurang memanfaatkan benda-benda nyata yang ada disekitarnya menyebabkan siswa kurang maksimal dalam belajar berhitung (Rinda, Robingatin, and Wildan, 2010).

Tabel 2 data distribusi frekuensi berhitung siswa dari beberapa penelitian yang menggunakan pemainan sebagai media berhitung (sebelum dan sesudah) berdasarkan beberapa kategori.

Tabel 2. Data Distribusi Frekuensi Berhitung siswa Berdasarkan Kategori

\begin{tabular}{|c|c|c|c|c|c|}
\hline \multirow{2}{*}{ No } & \multirow{2}{*}{ Data } & \multicolumn{4}{|c|}{ Siklus I } \\
\hline & & Amat Baik & Baik & Cukup & Kurang \\
\hline \multirow[t]{4}{*}{1.} & (Miswara, & - & 16,7 & 46,7 & 36,6 \\
\hline & Joko, \& Nia, & \multicolumn{4}{|c|}{ Siklus II } \\
\hline & 2018) & - & 60 & 30 & 10 \\
\hline & & \multicolumn{4}{|c|}{ Siklus I } \\
\hline \multirow[t]{3}{*}{2.} & (Juita, 2020) & 0 & 8,2 & 29,4 & 62,4 \\
\hline & & \multicolumn{4}{|c|}{ Siklus II } \\
\hline & & 22,6 & 66,8 & 10,6 & 0 \\
\hline
\end{tabular}

Terdapat perbedaan juga pada distribusi frekuensi berhitung siswa berdasarkan kategori amat baik, baik, cukup, dan kurang. Dimana persentasi nilai sesudah menggunakan permainan sebagai media pembelajaran lebih tinggi dibandingkan sebelum menggunakan permainan sebaga media pembelajaran. Hal tersebut dapat membuktikan bahwa media pembelajaran bebasis permainan efektif diterapkan agar kemampuan berhitung siswa dapat meningkat. Pada penelitian (Nataliya, 2015) menyatakan bahwa pembelajaran melalui permainan congklak sebagai media pembelajaran dapat meningkatkan kemampuan berhitung siswa hal tersebut dapat dibuktikan dari ketuntasan belajar.

Permainan pangkak igik karet sebagai media pembelajaran dapat memberikan kesan menyenangkan pada pelajaran karena melalui permainan siswa secara langsung akan terlibat sehingga dapat menumbuhkan rasa keinginan siswa untuk mencoba dan belajar serta rasa percaya diri siswa akan meningkat karena melalui permainan ini siswa akan mencoba yakin dengan kemampuan yang dimilikinya untuk memecahkan biji karet. Permainan ini juga dapat meningkatkan kemampuan berhitung karena di dalam permainan terdapat biji yang pecah dan tidak pecah lalu dikumpulkan dan siswa dapat menghitung berapa biji yang sudah pecah, berapa biji yang tidak pecah, dan berapa jumlah bii yang telah digunakan. Ada banyak permainan yang dapat digunakan dabagai media pembelajaran salah satunya adalah permainan dakon yang merupakan permainan tradisional masyarakat Jawa yang dapat melatih siswa pandai dalam berhitung (Mulyani, 2016). Pada penelitian (Mulyatna, Arfatin, \& Seruni, 2020) permainan bekel yang merupakan permainan tradisional yang menggunakan bola memantul dan biji bekel dan kelereng yang merupakan permainan yang biasanya terbuat dari kaca dan berbentuk bulat dapat diterapkan pada materi bilangan bulat, nilai tempat pada bilangan, ataupun satuan ukuran bisa digunakan sebagai media pembelajaran. Permainan tersebut 
dapat menjadikan matematika sebagai pelajaran yang menyenangkan dipelajari karena siswa yang karakteristiknya masih asyik dalam dunia bermain dapat lebih mudah menyerap materi pembelajaran khususnya pada pembelajaran matematika sehingga media pembelajaran berbasis permainan sangat efektif diterapkan. Jika siswa sudah paham akan konsep matematika maka akan lebih mudah bagi mereka untuk berhitung dan meningkatkan kemampuan berhitung.

Permainan dapat dimodifikasikan seperti permainan ular naga sebagai media pembelajaran dapat menjadikan media pembelajaran yang menyenangkan dan menarik dalam pembelajaran matematika yaitu konsep berhitung dan dapat berpengaruh terhadap perkembangan berhitung siswa (Sholihah \& Nur, 2019). Hal tersebut dikarenakan siswa lebih tertarik belajar menggunakan media pembelajaran permainan daripada hanya menggunakan lembar kerja siswa karena permainan dapat membangkitkan semangat siswa untuk belajar sehingga konsep berhitung akan lebih mudah dipahami oleh siswa dibandingkan dengan lembar kerja siswa. Dari beberapa hasil penelitian sebelumnya, dapat dinyatakan bahwa permainan efektif digunakan sebagai media berhitung untuk meningkatkan kemampuan berhitung siswa, begitu pula dengan permainan pangkak igik karet yang memanfaatkan biji karet sebagai wadah siswa untuk berhitung.

Di dalam permainan, terdapat hal-hal kebaikan di dalamnya dan dapat bermanfaat bagi perkembangan siswa baik fisik, emosi, kognitif, dan minat. Permainan yang cenderung kepada permainan yang mengedepankan kerja sama antar siswa dapat melatih dan mengontrol emosi tiap siswa. Permainan juga dapat berpengaruh terhadap perkembangan siswa (Hasanah \& Pratiwi, 2017). Pada penelitian (Mukhlis \& Mbelo, 2019) menggunakan 5 permainan tradisional dapat berpengaruh terhadap perkembangan sosial, perkembangan emosi siswa, dan perkembangan minat belajar siswa. Dalam permainan meong-meongan, pemahaman diri siswa akan terlihat karena siswa akan percaya diri menjadi pemain yang pertama melakukan permainan, kemampuan mengatur diri siswa akan meningkat karena siswa akan sabar menunggu giliran dalam permainan, perkembangan perilaku sosial siswa akan terlihat karena permainan ini adalah permainan yang mengajak kebersamaan, hubungan sosial antar siswa akan meningkat karena dalam permainan ini siswa akan saling memberikan dukungan.

Selain itu dalam permainan tradisional dolip, ular naga, balap karung, dan cina buta, pemahaman diri, kemampuan mengorganisasikan diri, perkembangan perilaku sosial, dan aspek pengambilan keputusan yang bertanggungjawab siswa akan terlihat dan meningkat hal tersebut didapatkan dari masing-masing aturan dan keseruan permainan. Sehingga permainan sebagai media pembelajaran dapat membuat siswa terus berkembang, berbagai aspek perkembangan sosial siswa akan terbentuk melalui permainan. Siswa dapat mengembangkan aspek perkembangan sosial emosional terkait manajemen diri, pengenalan diri, pengenalan sosial, kemampuan dan keterampilan membangun sebuah hubungan kepada siswa lain dan pengambilan keputusan yang bertanggungjawab melalui permainan tradisional. Pada penelitian (Lestari \& Siregar, 2017) menggunakan permainan engklek dapat mengembangkan keterampilan siswa yaitu keterampilan yang mengedepankan kerja sama 
kelompok, keterampilan dalam penyesuaian diri terhadap lingkungan sekitar, keterampilan dalam bertindak secara baik dengan siswa lain dan guru, keterampilan dalam mengontrol diri, mempunyai rasa empati, dapat menaati peraturan yang ada, dan dapat saling menghargai satu sama lain. Melalui permainan engklek siswa dapat dengan mudah bersosialisasi dengan teman sebayanya, siswa akan terbiasa akan sikap kooperatif dan sportif, siswa dapat menghargai teman dan dapat belajar mengendalikan dan mengontrol emosi, maka permainan tradisional sangat dibutuhkan untuk mengembangkan siswa dan membentuk keterampilan sosial siswa (Hasanah \& Pratiwi, 2017).

Pada penelitian (Mulyani, 2016) menggunakan permainan dakon yang merupakan permainan tradisional masyarakat Jawa dan dikenal juga di daerah lain dapat memperkenalkan nilai-nilai kebudayaan kepada siswa. Selain itu, permainan juga berpengaruh terhadap perkembangan siswa pada aspek kognitif dan motorik halus. Dari hasil beberapa penelitian sebelumnya, dapat dinyatakan bahwa permainan dapat membuat kesan menyenangkan bagi siswa sehingga dapat meningkatkan minat belajar siswa dalam mata pelajaran matematika, begitu pula dengan permainan pangkak igik karet yang dapat melatih siswa dalam menyusun strategi, serta dapat melatih siswa untuk bertindak teliti dan hati-hati, sehingga pola pikir siswa akan terasah dan terarah, dengan begitu siswa tidak akan merasa bosan dengan pelajaran.

\section{KESIMPULAN}

Berdasarkan uraian di atas, dapat disimpulkan bahwa permainan pangkak igik karet dapat diasumsikan sebagai media belajar untuk membangun konsep berhitung siswa, dapat meningkatkan kemampuan berhitung bagi siswa yang sudah mengenal dasar dan konsep berhitung, dapat memotivasi siswa dan siswa tidak lagi beranggapan bahwa matematika itu sulit karena permainan pangkak igik karet menyediakan lingkungan belajar yang menyenangkan, dapat mempengaruhi rasa nasionalisme dan kebanggaan siswa terhadap warisan seni, tradisi, dan budaya bangsa Indonesia, berpengaruh terhadap perkembangan siswa yaitu menumbuhkan dan meningkatkan rasa percaya diri, kedisiplinan, dan sikap kerjasama yang baik bagi siswa dan dapat meningkatkan minat belajar siswa, permainan pangkak igik karet sebagai media berhitung sangat efektif diterapkan pada pembelajaran matematika untuk meningkatkan kemampuan kognitif siswa. Diharapkan peneliti selanjutnya dapat melakukan penelitian lebih lanjut terkait pengembangan permainan pangkak igik karet sebagai media berhitung.

\section{UCAPAN TERIMAKASIH}

Ucapan terima kasih disampaikan kepada pihak Kementerian Riset dan Teknologi/Badan Riset dan Inovasi Nasional Republik Indonesia yang telah mendanai penelitian ini. Ucapan terima kasih juga disampaikan kepada pihak-pihak yang membantu pelaksanaan penelitian 


\section{DAFTAR PUSTAKA}

Agusti, F. A., Zafirah, A., Anwar, F., \& Syafril, S. (2018). The Implantation of Character Values toward Students through Congklak Game. Jurnal Penelitian Pendidikan, 35(2), 133 141. https://journal.unnes.ac.id/nju/index.php/JPP/article/view/13947

Agustin, M. D. A. (2019). Proses Berfikir Matematis Siswa Dalam Memecahkan Masalah Matematika Ditinjau Dari Tipe Kepribadian Keirsey. Madrosatuna: Journal of Islamic Elementary School, 2(2), 29. https://doi.org/10.21070/madrosatuna.v2i2.1967

Arista, L. O., Handayanto, A., \& Damayani, A. T. (2019). Efektivitas Model Pembelajaran Numbered-Head Together Berbantu Media Permainan Tradisional Engklek Terhadap Hasil Belajar Matematika Kelas III SDN Bendungan Semarang. Jurnal Guru Kita (JGK), 2(3), 4756. https://doi.org/10.1017/CBO9781107415324.004

Arsyad, A. (2011). Media Pembelajaran. PT Raja Grafindo Persada.

Fadlillah, M. (2016). Pengembangan Permainan Monraked Sebagai Media untuk Mestimulasi Kecerdasan Logika Matematika Anak Usia Dini. Jurnal CARE (Children Advisory Research and Education), 4(1), 9-23. http://e-journal.unipma.ac.id/index.php/JPAUD/article/view/579.

Fahmi, F. K. (2016). Pengembangan Media Games Education dalam Pembelajaran

Matematika. Jurnal Kajian Pendidikan Matematika, 01(02), 215-226. https://journal.lppmunindra.ac.id/index.php/jkpm/article/download/1189/1075

Falahudin, I. (2014). Pemanfaatan Media dalam Pembelajaran. Jurnal Lingkar Widyaiswara, 1(4), 104-117. https://juliwi.com/published/E0104/Paper0104_104-117.pdf

Handayani, K. D., Dantes, N., \& Lasmawan, W. (2013). Penerapan Permainan Tradisional Meong-Meongan Untuk Perkembangan Sikap Sosial Anak Kelompok B Taman Kanak-kanak Astiti Dharma Penatih Denpasar. Journal Program Pascasarjana Universitas Pendidikan Ganesha, 3(2013), 1-8. https://www.neliti.com/id/publications/119212/penerapan-permainantradisional-meong-meongan-untuk-perkembangan-sikap-sosial-an

Hariastuti, R. M. (2017). Permainan Tebak-tebak Buah Manggis: Sebuah Inovasi Pembelajaran Matematika Berbasis Etnomatematika. Jurnal Matematika Dan Pendidikan Matematika, 2(1), 25-35. https://journal.unipdu.ac.id/index.php/jmpm/article/view/776/604

Hasanah, N. I., \& Pratiwi, H. (2016). Pengembangan Anak Melalui Permainan Tradisional. Aswaja Pressindo.

Indrawati, D., \& Suardiman, S. P. (2013). Pengembangan Media Travel Game Untuk Pembelajaran Perkalian Dan Pembagian Bilangan Pecahan Matematika Sd Kelas V. Jurnal Prima Edukasi, 1(2), 135-146. https://doi.org/10.21831/jpe.v1i2.2631

Iswinarti. (2010). Nilai-nilai Terapiutik Permainan Tradisional Engklek Untuk Anak Usia

Sekolah Dasar. Naskah Publikasi. Penelitian Dasar Keilmuwan. Fakultas Psikologi. Universitas Muhammadiyah Malang.

Juita, R. (2012). Peningkatan Kemampuan Berhitung Anak Melalui Permainan Menakar Air 
di TK Aisyiyah Koto Kaciak Maninjau. Jurnal Pesona PAUD, 1(1), 1-9. http://ejournal.unp.ac.id/index.php/paud/article/view/1656/1426.

Laurens, T., Batlolona, F. A., Batlolona, J. R., \& Leasa, M. (2018). How Does Realistic

Mathematics Education (RME) Improve Students' Mathematics Cognitive Achievement? Eurasia Journal of Mathematics, Science and Technology Education, 14(2), 569-578. https://doi.org/10.12973/ejmste/76959

Lestari, W., \& Siregar, N. (2017). Peranan Permainan Tradisional Engklek Dalam

Mengembangkan Keterampilan Sosial Anak Usia Sekolah Dasar Di Desa Hamparan Perak. School Education Journal Pgsd Fip Unimed, 7(3), 305-311. https://jurnal.unimed.ac.id/2012/index.php/school/article/view/9253

Masyhur, F. (2017). Penelitian e-Government di Indonesia: Studi Literatur Sistematis dari

Perspektif Dimensi Pemeringkatan e-Government Indonesia (PeGI). JURNAL IPTEKKOM: Jurnal Ilmu Pengetahuan \& Teknologi Informasi, 19(1), 51-62. https://www.neliti.com/id/publications/228118/penelitian-e-government-di-indonesia-studiliteratur-sistematis-dari-perspektif

Miswara, A., Joko, W., \& Nia, L. A. (2018). Pengaruh Permainan Congklak Terhadap Peningkatan Kemampuan Berhitung Anak Usia 4-6 Tahun di TK Dharma Wanita Persatuan $02 \quad$ Malang. Nursing News, 3(1), 697-706. https://publikasi.unitri.ac.id/index.php/fikes/article/view/841/654

Mukhlis, A., \& Mbelo, F. H. (2019). Analisis Perkembangan Sosial Emosional Anak Usia Dini Pada Permainan Tradisional. Preschool (Jurnal Perkembangan dan Pendidikan Anak Usia Dini, $\quad$ l(1), 11-28. http://ejournal.uinmalang.ac.id/index.php/preschool/article/view/8172.

Mulyani, N. (2016). Super Asyik Permainan Tradisional Anak Indonesia. DIVA Press.

Mulyatna, F., Arfatin, N., \& Seruni. (2020). Pembelajaran Matematika SD / MI yang Inovatif Melalui Permainan. Jurnal Pengabdian Community, 2(2), 52-58. https://community.ejournal.unsri.ac.id/index.php/community/article/ view/27/18

Muzdalipah, I., \& Yulianto, E. (2015). Pengembangan Desain Pembelajaran Matematika untuk Siswa SD Berbasis Aktivitas Budaya dan Permainan Tradisional Masyarakat Kampung $\begin{array}{llll}\text { Naga. } & \text { Jurnal } & \text { Siliwangi, } & \text { 63-74), }\end{array}$ http://jurnal.unsil.ac.id/index.php/jspendidikan/article/view/18/20.

Nataliya, P. (2015). Efektivitas Penggunaan Media Pembelajaran Permainan Tradisional Congklak Untuk Meningkatkan Kemampuan Berhitung Pada Siswa Sekolah Dasar. Jurnal Ilmiah Psikologi Terapan, 342), 343-358. http://ejournal.umm.ac.id/index.php/jipt/article/view/3536.

Novianti, R. (2015). Pengembangan Permainan Roda Putar untuk Meningkatkan Kemampuan 
Berhitung Angka Anak Usia 5-6 Tahun. Jurnal Educhild, 4(1), 56-63. https://educhild.ejournal.unri.ac.id/index.php/JPSBE/article/view/2803/2736.

Pane, A., \& Muhammad. D. D. (2017). Belajar dan Pembelajaran. Jurnal Kajian Ilmu-ilmu
Keislaman,
$3(2)$,
$333-352$.
http://jurnal.iain-

padangsidimpuan.ac.id/index.php/F/article/download/945/795.

Prasetya, Y. E., \& Siti, K. (2016). Pengembangan Media Permainan Kartu Kwartet Dalam

Pembelajaran Matematika Pada Materi Pokok Segitiga Dan Segiempat. MATHEdunesa, 5(1), 95-101.

https://jurnalmahasiswa.unesa.ac.id/index.php/mathedunesa/article/view/16673/15144.

Rahmatin, R. (2016). Pengembangan Media Permainan Kartu Umath (Uno Mathematics)

Dalam Pembelajaran Matematika Pada Materi Pokok Operasi Bilangan Bulat. MATHEdunesa,

$67-73$.

https://jurnalmahasiswa.unesa.ac.id/index.php/mathedunesa/article/view/16667/15138.

Rinda, Robingatin, \& Wildan, S. (2010). Peningkatan Kemampuan Berhitung Melalui

Permainan Tradisional Dakon di Raudhatul Athfal Al Kamal 1 Palaran Samarinda. Jurnal Ilmiah

PESONA

PAUD,

$7(1)$,

$1-14$.

http://ejournal.unp.ac.id/index.php/paud/article/view/108472/103492

Rizal, A., \& Hernawati, K. (2017). Pengembangan Game Edukasi Matematika Dengan

Pendekatan Guided Discovery Untuk Siswa Smp Kelas Viii. Jurnal Pendidikan Matematika, $6(3)$

$1-8$.

http://journal.student.uny.ac.id/ojs/ojs/index.php/pmath/article/download/6660/6423.

Rukiah, H. (2018). Meningkatkan Kemampuan Operasi Hitung Siswa pada Pembelajaran

Matematika dengan Menggunakan Permainan Kartu di Kelas II SDN Habau Tahun Pelajaran 2016 / 2017. Jurnal Penelitian Tindakan dan Pendidikan, 4(2), 9-20. https://rumahjurnal.net/index.php/ptp/article/view/478.

Sakarti, H. (2018). Hubungan Kecemasan dan Kemampuan Siswa dalam Menyelesaikan

Masalah Matematika. Jurnal Pendidikan Informatika dan Sains (JPIS), 7(1), 28-41. https://journal.ikippgriptk.ac.id/index.php/saintek/article/view/766/685.

Sari, C. K., Muslihatun, A., Cahyaningtyas, L., Khaimmudin, R. N. L. H., Fijatullah, R. N., \&

Nisa', E. U. (2019). Pemanfaatan Permainan Tradisional untuk Media Pembelajaran:

Congklak Bilangan sebagai Inovasi Pembelajaran Matematika Sekolah Dasar. Transformasi:

Jurnal Pengabdian Masyarakat, $\quad 15(1), \quad$ 14-22.

https://doi.org/10.20414/transformasi.v15i1.915

Sholihah, I., \& Nur, I. S. R. (2019). Pengaruh Permainan Tradisional Ular Naga Modifikasi

Terhadap Aspek Perkembangan Kemampuan Berhitung Anak Usia 5-6 Tahun. Jurnal Mahasiswa Unesa, 8(1), 1-7. https://jurnal mahasiswa.unesa.ac.id/index.php/paudteratai/article/view/28500/26078 
Siregar, N., \& Lestari, W. (2018). Peranan Permainan Tradisional Dalam Mengembangkan Kemampuan Matematika Anak Usia Sekolah Dasar. Jurnal Mercumatika : Jurnal Penelitian Matematika Dan Pendidikan Matematika, 2(2), 1-7. http://ejurnal.mercubuanayogya.ac.id/index.php/mercumatika/article/view/427/362

Susanti, F., Siswati, \& Prasetyo, B. W. (2010). Pengaruh Permainan Tradisional Terhadap Kompetensi Interpersonal dengan Teman Sebaya pada Siswa SD (Studi Eksperimental pada Siswa Kelas 3 SDN Srondol Wetan 05-08). Jurnal Psikologi, 8(2), 145-155. https://ejournal.undip.ac.id/index.php/psikologi/article/view/2959/2645

Susanto, A. (2011). Perkembangan Anak Usia Dini: Pengantar dalam Berbagai Aspeknya. Kencana Prenada Media Group.

Widiyahti, U. N., Suprapto, E., \& Adamura, F. (2015). Pengembangan Media Pembelajaran Matematika Berkarakter Melalui Permainan Edukatif Matcindo Sebagai Learning Exercise Bagi Siswa. JIPM (Jurnal Ilmiah Pendidikan Matematika), 4(1), 59. https://10.25273/jipm.v4i1.839.

Ulya, H. (2017). Permainan Tradisional Sebagai Media dalam Pembelajaran Matematika.

Prosiding Seminar Nasional Pendidikan Semnasdik FKIP Universitas Muhammadiyah Metro, 371-376. https://repository.ummetro.ac.id /files/semnasdik/967b29a8033b7621321b15c78166e74a.pdf 